\title{
sciendo
}

Folia Oeconomica Stetinensia

Volume 20 (2020) Issue 2

DOI: $10.2478 /$ foli-2020-0047
WYDZIAL NAUK EKONOMICZNYCH I ZARZADZANIA

\section{APPLICATION OF THE PARTIAL TRIADIC ANALYSIS METHOD TO ANALYZE THE CRIME RATE IN POLAND IN THE YEARS 2000-2017}

Małgorzata Misztal, Ph.D.

University of Łódź

Faculty of Economics and Sociology

Department of Statistical Methods

Rewolucji 1905 r. no 41, 90-214 Łódź, Poland

e-mail: malgorzata.misztal@uni.lodz.pl

ORCID: 0000-0002-8719-2097

Received 8 February 2020, Accepted 12 October 2020

\begin{abstract}
Research background: Crime is a complex social phenomenon studied by scientists from various disciplines, as well as being of interest to politicians and the general public. Although the decrease in the level of crime has been observed in Poland in recent years, there is still a need to search for effective methods of investigating the phenomenon of crime in a multidimensional perspective.

Purpose: The aim of the paper is to assess the spatial and temporal diversity of the chosen criminal offences categories in Poland from 2000 to 2017.

Research methodology: The analyzed dataset constitutes a data cube: objects $\mathrm{x}$ variables $\mathrm{x}$ time. This type of data requires the use of methods dealing with three-way data structures, therefore the Partial Triadic Analysis, belonging to the STATIS family methods, was successfully applied.

Results: The structure of crime by voivodeship was fairly stable during the analyzed years. Three clusters of voivodeships similar in terms of the criminal crime rate were determined. The Podkarpackie Voivodeship was characterized by the most stable structure of criminal crime in the considered period. In contrast, noticeable changes in the crime structure over time were observed in the Opolskie, Dolnośląskie, Mazowieckie and Małopolskie Voivodeships. The highest variability was observed for crimes under The Act on Counteracting Drug Addiction.

Novelty: To the best knowledge of the author, there are no papers on the level of crime using the PTA method for analysis.
\end{abstract}

Keywords: crime, criminal offence, STATIS methodology, Principal Component Analysis, Partial Triadic Analysis, factorial maps

JEL classification: C38, K42 


\section{Introduction}

Crime is a complex phenomenon which is of interest to many scientific disciplines including sociology, psychology, criminology and economics. According to Florczak (2013, p. 7), there are at least three reasons for investigating crime. Firstly, ensuring social order and the rule of law is a fundamental duty of any organized society. As crime increases, the public perception of both the economy and the government deteriorates. Secondly, a high crime negatively affects the growth of social capital, which largely determines long-term economic growth. Thirdly, crime leads to many social costs. Moreover, actions aimed at reducing the level of crime require incurring costs resulting from the functioning of the law enforcement system.

Poland is in the group of EU countries with the highest government funds dedicated to the public order and safety. According to the Eurostat data, ${ }^{1}$ in 2017 it was $2.1 \%$ of GDP, while the EU average was $1.7 \%$. It should be emphasized that the expenditures on police services and law courts were higher in Poland than the EU average, respectively $1.1 \%$ of GDP against the EU-28 average equal to $0.9 \%$ and $0.5 \%$ of GDP while the EU-28 average was $0.3 \%$.

Poland is considered to be relatively safe compared to other European countries. According to the Police ${ }^{2}$ data, detectability of crimes in Poland in 2018 increased by $1.6 \%$ in comparison to 2017. The crime rate for the seven most serious crimes, the most troublesome for citizens, decreased by $4.8 \%$ compared to 2017 and the detectability of these crimes increased by $1.2 \%$.

According to the latest CBOS research, ${ }^{3} 75 \%$ of Poles positively assess the Police's activities. $89 \%$ of Poles perceive Poland as a safe country, and $98 \%$ of the respondents declare that they feel safe in their place of residence. ${ }^{4}$

However, regardless of the observed positive trend of a decrease in the crime rate and an increase in the sense of safety of the Poles, there is still a need to search for effective methods of investigating the phenomenon of crime in a multidimensional perspective. Analyzing crime scientifically, with the use of proper statistical methods, can support criminologists, the police and, finally, the government and the local authorities in their activities to reduce crime.

In Polish literature a lot of research papers using simple and advanced statistical methods to analyze the crime rate in Poland (also in comparison with the EU countries) can be found. Econometric models were used by Sztaudynger and Sztaudynger (2003), Bieniek, Cichocki

\footnotetext{
1 https://ec.europa.eu/eurostat/statistics-explained/index.php/Government_expenditure_on_public_order_and_safety (27.10.2019).

2 http://www.policja.pl/pol/aktualnosci/168195,Mniej-przestepstw-kryminalnych-wieksza-skutecznosc-iwykrywalnosc-Policja-podsum.html (27.10.2019).

3 https://www.cbos.pl/SPISKOM.POL/2019/K_118_19.PDF 15.10.2019).

4 https://www.cbos.pl/SPISKOM.POL/2019/K_072_19.PDF (15.10.2019).
} 
and Szczepaniec (2012), Florczak (2013), Kądziołka (2014, 2015a) and Lusawa (2016), spatial data analysis methods by Mordwa (2013) and Kądziołka (2016a) and panel models by Kądziołka (2015b). A proposal to analyze crime in Poland with the use of Weber's median-based taxonomic measure of development was presented in Bąk (2015), the Hellwig's taxonomic measure of development was applied to analyze the spatial diversity of crime level in Polish voivodeships by Bąk and Szczecińska (2015), the synthetic taxonomic measure of development for the analysis of public safety in European countries was used by Wierzbicka and Żółtaszek (2015) and for the analysis of the crime rate in the EU-28 countries by Bąk and Cheba (2018). Hierarchical clustering, as well as regression trees, were applied by Kądziołka (2015c, 2016b, 2016c). An attempt to use a redundancy analysis to investigate crime against property in Poland was made in the papers of Misztal $(2017,2018)$. The classical principal component analysis (PCA) was used by Leżoń (2015) to study the crime rate in EU countries. Also, the rather infrequently used PCA-based methods: the between-class and within-class PCA were applied by Misztal (2019).

The aim of this study is to assess the spatial and temporal diversity of the selected categories of criminal offences in Poland over a period of 18 years - specifically from 2000 to 2017. Since the examined data constitute a sequence of 18 two-way tables (one for each year), the so-called $K$-table approach was used for the analysis (Thioulouse, 2011; Thioulouse et al., 2018). A joint analysis of a series of data tables instead of a series of separate analyzes should facilitate answering the following questions: (1) are all the tables structured in the same way? (2) Is it possible to find a common part among all the tables? (3) Are there any changes from one table to another?

According to Thioulouse (2011, p. 2303) $K$-table analysis methods belong to the following three families: STATIS, Multiple Factor Analysis (MFA) and Multiple Co-Inertia Analysis (MCOIA). In this research the Partial Triadic Analysis (PTA) method, derived from the STATIS family methods, was applied. To the best knowledge of the author, there are no studies on the level of crime in Poland or any other country, which are based on the PTA method.

\section{Data and methods}

The analysis was based on the data available on the Polish Police website. ${ }^{5}$ The datasets for the voivodeships cover the period from 2000 to 2017. Ten types of criminal offences were taken into account: property damage $\left(\mathrm{X}_{1}\right)$, robbery $\left(\mathrm{X}_{2}\right)$, burglary $\left(\mathrm{X}_{3}\right)$, car theft $\left(\mathrm{X}_{4}\right)$, property theft

\footnotetext{
5 http://www.statystyka.policja.pl (5.09.2019).
} 
$\left(\mathrm{X}_{5}\right)$, participation in violence or assault $\left(\mathrm{X}_{6}\right)$, damage to health $\left(\mathrm{X}_{7}\right)$, homicide $\left(\mathrm{X}_{8}\right)$, rape $\left(\mathrm{X}_{9}\right)$ and drugs - crimes under The Act on Counteracting Drug Addiction $\left(\mathrm{X}_{10}\right)$. The choice of these types was dictated mainly by the data availability for individual voivodeships. The voivodeships differ in terms of population, so all the analyzed crime categories were presented in the form of the crime intensity per 100,000 inhabitants.

The dataset used in the analysis consists of $K=18$ tables and constitutes the so-called data cube: objects $(n=16$ voivodeships $) \times$ variables $(p=10$ types of crimes $) \times$ time $(18$ years $)$ - see Figure 1. This type of data requires the use of methods dealing with the three-way data structures; the Partial Triadic Analysis is one of them.



Figure 1. The analyzed three-way data structure

Source: own elaboration.

The Partial Triadic Analysis belongs to the STATIS (Structuration des Tableaux à Trois Indices de la Statistique) family methods (Stanimirova et al., 2004; Abdi, Williams, Valentin, Bennani-Dosse, 2012; Thioulouse et al., 2018). STATIS is a generalization of the principal component analysis designed for an analysis of several sets of variables collected on the same set of observations. According to Abdi et al. (2012, p. 125) there are three steps of the STATIS methods: (1) to compare and analyze the relationships between the different datasets (the Interstructure step), (2) to integrate these datasets into an optimum weighted average called a Compromise, which is then analyzed with the use of PCA to reveal the common structure between the observations (the Compromise step), and (3) to project each of the original datasets onto the Compromise to analyze commonalities and discrepancies (the Intrastructure step). 
PTA is a particular case of STATIS used when the same variables are measured on the same observations at different times (i.e. all the analyzed tables have the same rows and columns). A more formal description of the PTA method, based on the papers by Thioulouse (2011) and Thioulouse et al. (2018, pp. 176-177), is briefly summarized below.

Let $\mathbf{X}_{1}, \ldots, \mathbf{X}_{k}$ be $k$ tables of quantitative variables with the same $n$ rows (objects) and the same $p$ columns (variables). Let $\left(\mathbf{X}_{1}, \mathbf{Q}, \mathbf{D}\right) \ldots\left(\mathbf{X}_{k}, \mathbf{Q}, \mathbf{D}\right)$ be the associated statistical triplets. $\mathbf{Q}$ is a $p \times p$ positive symmetric matrix, which is a metric used as an inner product in $\mathbb{R}^{p}$ allowing to measure distances between the $n$ objects and $\mathbf{D}$ is a $n \times n$ positive symmetric matrix, which is a metric used as an inner product in $\mathbb{R}^{n}$ allowing to measure the links between the $p$ variables.

The Interstructure analysis is based on the concepts of vector variance, vector covariance and vector correlation (Escoufier, 1973).

For two tables $\mathbf{X}_{k}$ and $\mathbf{X}_{l}$ with the same $n$ rows and the same $p$ columns and the two associated statistical triplets $\left(\mathbf{X}_{k}, \mathbf{Q}, \mathbf{D}\right)$ and $\left(\mathbf{X}_{l}, \mathbf{Q}, \mathbf{D}\right)$, the vector covariance between the tables is defined as:

$$
\operatorname{Covv}\left(\mathbf{X}_{k}, \mathbf{X}_{l}\right)=\operatorname{tr}\left(\mathbf{X}_{k}^{T} \mathbf{D} \mathbf{X}_{l} \mathbf{Q}\right)=\operatorname{tr}\left(\mathbf{X}_{l}^{T} \mathbf{D} \mathbf{X}_{k} \mathbf{Q}\right)
$$

The vector variance $\operatorname{Vav}\left(\mathbf{X}_{k}\right)$ is equal to:

$$
\operatorname{Vav}\left(\mathbf{X}_{k}\right)=\operatorname{Covv}\left(\mathbf{X}_{k}, \mathbf{X}_{k}\right)=\operatorname{tr}\left(\mathbf{X}_{k}^{T} \mathbf{D} \mathbf{X}_{k} \mathbf{Q}\right)
$$

The vector correlation coefficient (the RV coefficient) can be defined as:

$$
\operatorname{RV}\left(\mathbf{X}_{k}, \mathbf{X}_{l}\right)=\frac{\operatorname{Covv}\left(\mathbf{X}_{k}, \mathbf{X}_{l}\right)}{\sqrt{\operatorname{Vav}\left(\mathbf{X}_{k}\right)} \sqrt{\operatorname{Vav}\left(\mathbf{X}_{l}\right)}}
$$

For tables that contain only standardized variables $\operatorname{Covv}\left(\mathbf{X}_{k}, \mathbf{X}_{l}\right)=\sum_{i=1}^{p} \operatorname{cor}\left(\mathbf{X}_{k}^{i}, \mathbf{X}_{l}^{i}\right)$ and $\operatorname{Vav}\left(\mathbf{X}_{k}\right)=p$. Therefore, the RV coefficient is the average of the correlations between all of the pairs of corresponding variables:

$$
\operatorname{RV}\left(\mathbf{X}_{k}, \mathbf{X}_{l}\right)=\frac{1}{p} \sum_{i=1}^{p} \operatorname{cor}\left(\mathbf{X}_{k}^{i}, \mathbf{X}_{l}^{i}\right)
$$

The RV coefficients computed for each pair of the tables $\left(\mathbf{X}_{k}, \mathbf{X}_{l}\right)$ form the $\mathbf{R V}$ matrix, which is the basis for the further analysis. ${ }^{6}$ The eigenvalues $\boldsymbol{\Lambda}_{\text {INTER }}$ and the normed eigenvectors $\mathbf{U}_{I N T E R}$ of the $\mathbf{R V}$ matrix are used to compute the scores of tables:

\footnotetext{
${ }^{6}$ Remark: $0 \leq \operatorname{RV}\left(\mathbf{X}_{k}, \mathbf{X}_{l}\right) \leq 1$.
} 


$$
\mathbf{S}=\mathbf{U}_{\text {INTER }} \Lambda_{I N T E R}^{1 / 2}
$$

These scores can be viewed through a correlation circle.

The Compromise analysis is carried out on the basis of the results obtained in the Interstructure step.

Let $\mathbf{u}_{\text {INTER }}^{T}=\left(\alpha_{1}, \alpha_{2}, \ldots, \alpha_{K}\right), \sum_{k=1}^{K} \alpha_{k}^{2}=1$ be the first eigenvector of the Interstructure analysis. For $k=1, \ldots, K, \alpha_{k}$ represents the weight of the $\mathbf{X}_{k}$ table. The Compromise table is then determined as:

$$
\mathbf{X}_{C}=\sum_{k=1}^{K} \alpha_{k} \mathbf{X}_{k}
$$

The Compromise table $\mathbf{X}_{C}$ is a linear combination of the $K$ initial tables, weighted by the components of the first eigenvector of the Interstructure step. The analysis of the Compromise is an analysis of the statistical triplet: $\left(\mathbf{X}_{C}, \mathbf{Q}, \mathbf{D}\right)$ with the use of PCA.

The row scores $(\mathbf{L})$ projection of the rows of $\mathbf{X}_{C}$ onto the principal axes (A) and the column scores $(\mathbf{C})$ projection of the columns of $\mathbf{X}_{C}$ onto the principal components $(\mathbf{B})$ are respectively given by:

$$
\begin{aligned}
& \mathbf{L}=\mathbf{X}_{C} \mathbf{Q A} \\
& \mathbf{C}=\mathbf{X}_{C}^{T} \mathbf{D B}
\end{aligned}
$$

It is also possible to compute the RV coefficient between the Compromise table $\mathbf{X}_{C}$ and each of the $K$ initial tables: $\operatorname{RV}\left(\mathbf{X}_{C}, \mathbf{X}_{k}\right)$ which represents the squared cosine $\left(\cos ^{2}\right)$, i.e. it is a measure of how far the Compromise reflects the information contained in each of the $K$ initial tables.

The Intrastructure analysis results are obtained by projecting the rows and columns of each of the initial tables onto the Compromise step results in order to assess the reproducibility of the structure across the series of $K$ tables.

Let $\boldsymbol{\Lambda}$ be the eigenvalues and $\mathbf{A}$ the eigenvectors of the Compromise analysis of the triplet: $\left(\mathbf{X}_{C}, \mathbf{Q}, \mathbf{D}\right)$. The rows of each initial table are projected onto the principal axes:

$$
\mathbf{R}_{k}=\mathbf{X}_{k} \mathbf{Q A}
$$

The columns of each initial table are projected onto the principal components:

$$
\mathbf{C}_{k}=\mathbf{X}_{k}^{T} \mathbf{D B}
$$


The principal axes $\mathbf{A}_{k}$ of the separate analysis of the $k$-th table can be projected onto the principal axes $\mathbf{A}$ of the Compromise study: $\mathbf{A}_{k}^{T} \mathbf{Q A}$. Similarly, the principal components $\mathbf{B}_{k}$ of the separate analysis of the $k$-th table can be projected onto the principal components $\mathbf{B}$ of the Compromise study: $\mathbf{B}_{k}^{T} \mathbf{D B}$.

All of the calculations were performed with the use of the R-environment (packages: ade4, adegraphics).

\section{Results}

\subsection{Interstructure analysis}

The first step of the PTA (the Interstructure step) searches for the similarities between the 18 analyzed years regarding the structure of the criminal crime, which is based on the computation of the RV coefficient matrix (see Table 1). The three highest and three lowest $\mathrm{RV}$ coefficients are bolded.

Table 1. Matrix of the vector correlation coefficients between the tables (RV)

\begin{tabular}{|c|c|c|c|c|c|c|c|c|c|c|c|c|c|c|c|c|c|c|}
\hline Years & 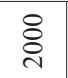 & 홍 & ণ্ণ & 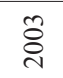 & ঠ্ণ & $\stackrel{n}{8}$ & ঃ & 홍 & 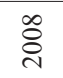 & ஓి & $\stackrel{\circ}{\stackrel{0}{\circ}}$ & $\bar{\Xi}$ & $\stackrel{\sim}{\stackrel{\sim}{\sim}}$ & $\stackrel{m}{\stackrel{n}{\sim}}$ & 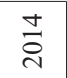 & $\frac{n}{\stackrel{n}{d}}$ & $\begin{array}{l}0 \\
\stackrel{\sim}{*}\end{array}$ & $\stackrel{-}{\circ}$ \\
\hline 2000 & 1 & & & & & & & & & & & & & & & & & \\
\hline 2001 & 0.90 & 1 & & & & & & & & & & & & & & & & \\
\hline 2002 & 0.86 & 0.93 & 1 & & & & & & & & & & & & & & & \\
\hline 2003 & 0.86 & 0.89 & 0.90 & 1 & & & & & & & & & & & & & & \\
\hline 2004 & 0.82 & 0.86 & 0.86 & 0.92 & 1 & & & & & & & & & & & & & \\
\hline 2005 & 0.77 & 0.86 & 0.86 & 0.87 & 0.93 & 1 & & & & & & & & & & & & \\
\hline 2006 & 0.72 & 0.78 & 0.79 & 0.85 & 0.89 & 0.89 & 1 & & & & & & & & & & & \\
\hline 2007 & 0.74 & 0.75 & 0.77 & 0.80 & 0.85 & 0.84 & 0.89 & 1 & & & & & & & & & & \\
\hline 2008 & 0.72 & 0.77 & 0.75 & 0.81 & 0.82 & 0.84 & 0.84 & 0.90 & 1 & & & & & & & & & \\
\hline 2009 & 0.68 & 0.72 & 0.68 & 0.73 & 0.76 & 0.78 & 0.82 & 0.87 & 0.88 & 1 & & & & & & & & \\
\hline 2010 & 0.68 & 0.69 & 0.63 & 0.76 & 0.76 & 0.73 & 0.77 & 0.81 & 0.82 & 0.84 & 1 & & & & & & & \\
\hline 2011 & 0.68 & 0.70 & 0.66 & 0.74 & 0.76 & 0.76 & 0.78 & 0.85 & 0.86 & 0.84 & 0.86 & 1 & & & & & & \\
\hline 2012 & 0.63 & 0.71 & 0.69 & 0.72 & 0.74 & 0.74 & 0.73 & 0.81 & 0.86 & 0.82 & 0.82 & 0.87 & 1 & & & & & \\
\hline 2013 & 0.66 & 0.67 & 0.63 & 0.71 & 0.73 & 0.71 & 0.76 & 0.82 & 0.85 & 0.81 & 0.79 & 0.84 & 0.84 & 1 & & & & \\
\hline 2014 & 0.74 & 0.75 & 0.70 & 0.75 & 0.78 & 0.77 & 0.75 & 0.82 & 0.82 & 0.79 & 0.76 & 0.81 & 0.81 & 0.80 & 1 & & & \\
\hline 2015 & 0.70 & 0.72 & 0.67 & 0.70 & 0.75 & 0.76 & 0.72 & 0.78 & 0.80 & 0.76 & 0.75 & 0.79 & 0.84 & 0.80 & 0.90 & 1 & & \\
\hline 2016 & 0.68 & 0.69 & 0.63 & 0.68 & 0.71 & 0.74 & 0.72 & 0.76 & 0.75 & 0.78 & 0.78 & 0.79 & 0.79 & 0.76 & 0.87 & 0.87 & 1 & \\
\hline 2017 & 0.69 & 0.71 & 0.66 & 0.71 & 0.74 & 0.74 & 0.72 & 0.77 & 0.78 & 0.75 & 0.74 & 0.78 & 0.80 & 0.77 & 0.86 & 0.85 & 0.88 & 1 \\
\hline
\end{tabular}

Source: own elaboration. 
When analyzing the RV coefficients in Table 1, it can be observed that the pairs of years 2001 and 2002, 2003 and 2004, 2004 and 2005 are the most similar with the RV coefficients respectively equal to $0.93,0.92$ and 0.93 . On the other hand, the following couples of years: 2002 and 2010, 2002 and 2013, 2002 and 2016 are the most different in terms of the structure of the crime, with the RV coefficient of 0.63 .

Taking into account the distances between the pairs of tables (Robert, Escoufier, 1976): $\operatorname{Dist}^{2}\left(\mathbf{X}_{k}, \mathbf{X}_{l}\right)=2\left[1-\operatorname{RV}\left(\mathbf{X}_{k}, \mathbf{X}_{l}\right)\right]$, two groups of similar tables can be identified (Figure 2) - the first one covers the period 2000-2006 and the second one - the period 2007-2017 (in this cluster, two subgroups can be observed as well, specifically one covering the years 2007-2013 and the second one for 2014-2017).

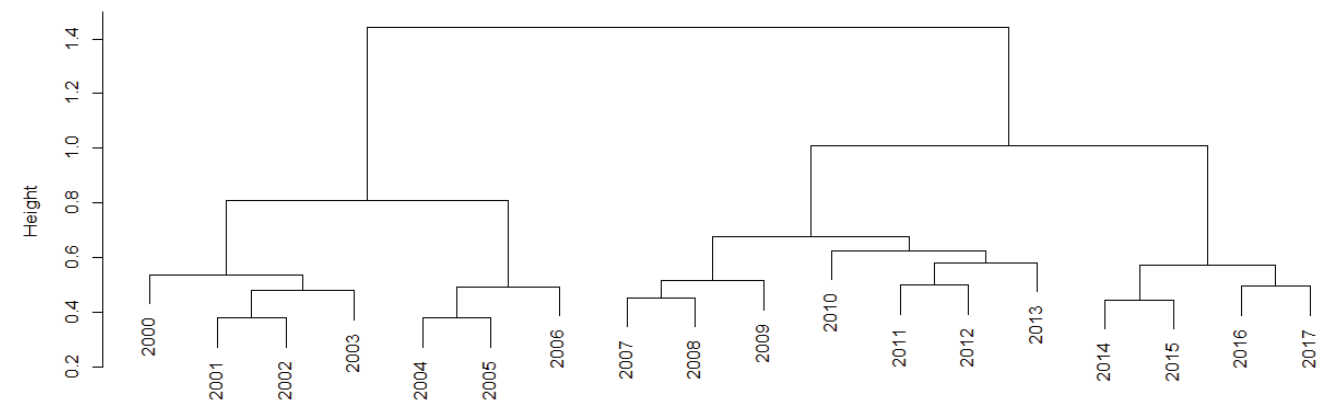

Figure 2. Clusters of years obtained by Ward's method

Source: own elaboration.

The PCA of the RV matrix reveals that the first axis, representing $79.2 \%$ of the total inertia, is strongly dominant (see Figure 3). The projection of the years onto the first and second axes provides an overview of the similarity between the analyzed 18 two-way tables: voivodeships $\times$ crimes.

When analyzing the correlation circle in Figure 3 it can be observed that all of the annual tables have similar and high coordinates on the first axis, which indicates the existence of the strong common spatial structure regarding the crime. On the second axis, representing $6.4 \%$ of the total inertia, the Interstructure analysis highlights the differences between the period 2002-2006 and 2007-2017.

The contribution of each table in the construction of the Compromise is presented in Table 2, where $\alpha_{k}$ represents the weight of the $\mathbf{X}_{k}$ table in the definition of the Compromise table. 


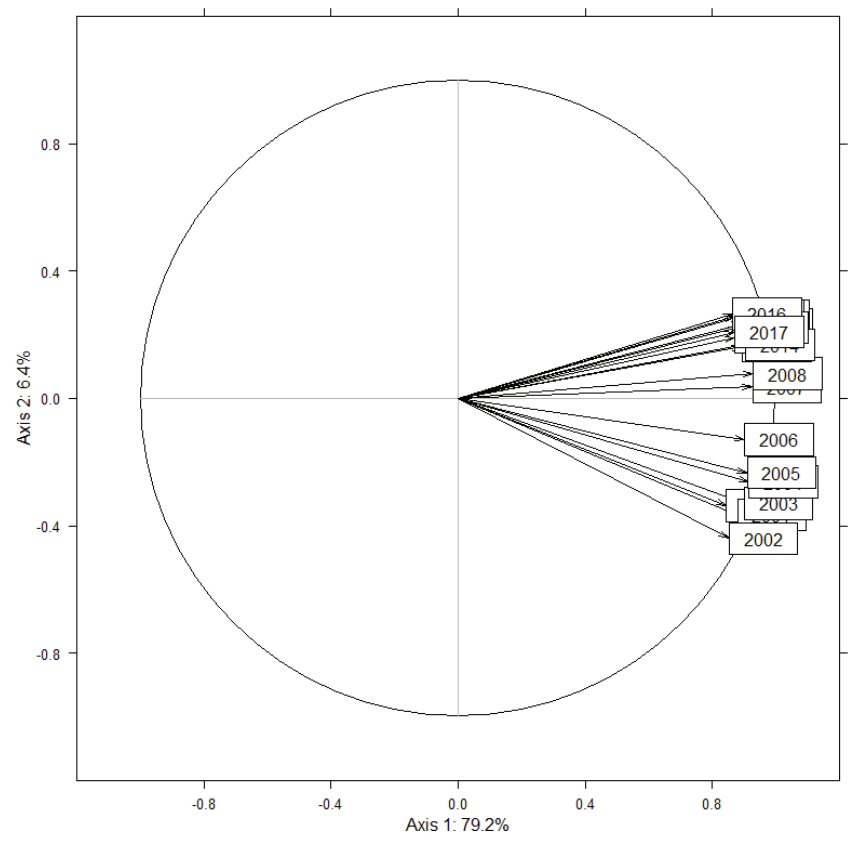

Figure 3. Similarities between the analyzed 18 years - the Interstructure correlation circle Source: own elaboration.

Table 2. Tables weights $\left(\alpha_{k}\right)$ and the quality index of the Compromise's structure $\left(\cos ^{2}\right)$

\begin{tabular}{|c|c|c|c|c|c|c|c|c|}
\hline Year & $\alpha_{k}$ & $\cos ^{2}$ & Year & $\alpha_{k}$ & $\cos ^{2}$ & Year & $\alpha_{k}$ & $\cos ^{2}$ \\
\hline 2000 & 0.2238 & 0.845 & 2006 & 0.2390 & 0.902 & 2012 & 0.2352 & 0.888 \\
\hline 2001 & 0.2329 & 0.880 & 2007 & 0.2456 & 0.927 & 2013 & 0.2307 & 0.871 \\
\hline 2002 & 0.2260 & 0.853 & 2008 & 0.2462 & 0.930 & 2014 & 0.2397 & 0.905 \\
\hline 2003 & 0.2386 & 0.901 & 2009 & 0.2369 & 0.895 & 2015 & 0.2343 & 0.884 \\
\hline 2004 & 0.2427 & 0.916 & 2010 & 0.2308 & 0.871 & 2016 & 0.2293 & 0.866 \\
\hline 2005 & 0.2411 & 0.910 & 2011 & 0.2378 & 0.898 & 2017 & 0.2306 & 0.871 \\
\hline
\end{tabular}

Source: own elaboration.

It can be observed that the weights for all of the tables are quite similar. Years 2008 and 2007 have the largest contribution to the Compromise table with weights of 0.2462 and 0.2456 respectively, and year 2000 with a weight of 0.2238 , represents the smallest contribution. As one can see, in the Compromise table a greater importance is given to the tables that have a similar structure, so the Compromise represents the temporally stable part of the spatial structure of criminality. 
The next measure presented in Table 2 is the squared cosine $\left(\cos ^{2}\right)$. It is an indicator of how far the Compromise reflects the information contained in each of the initial tables. The table for year 2008 is the one that fits best with the Compromise $\left(\cos ^{2}=0.930\right)$, followed by the table for year $2007\left(\cos ^{2}=0.927\right)$. The table for year 2000 is the worst represented by the Compromise with $\cos ^{2}=0.845$.

\subsection{Compromise analysis}

The quality of the Compromise can be assessed as the ratio of the first eigenvalue of the RV matrix to the sum of the all eigenvalues (Abdi, Valentin, 2007, p. 959) i.e. it is equal to $\frac{14.255}{18}=0.792$. Thus, the Compromise represents $79.2 \%$ of the inertia of the original set of the analyzed data tables.

The first two axes of the Compromise analysis explain $77.2 \%$ of the total inertia of the Compromise. The Compromise biplot is presented in Figure 4.

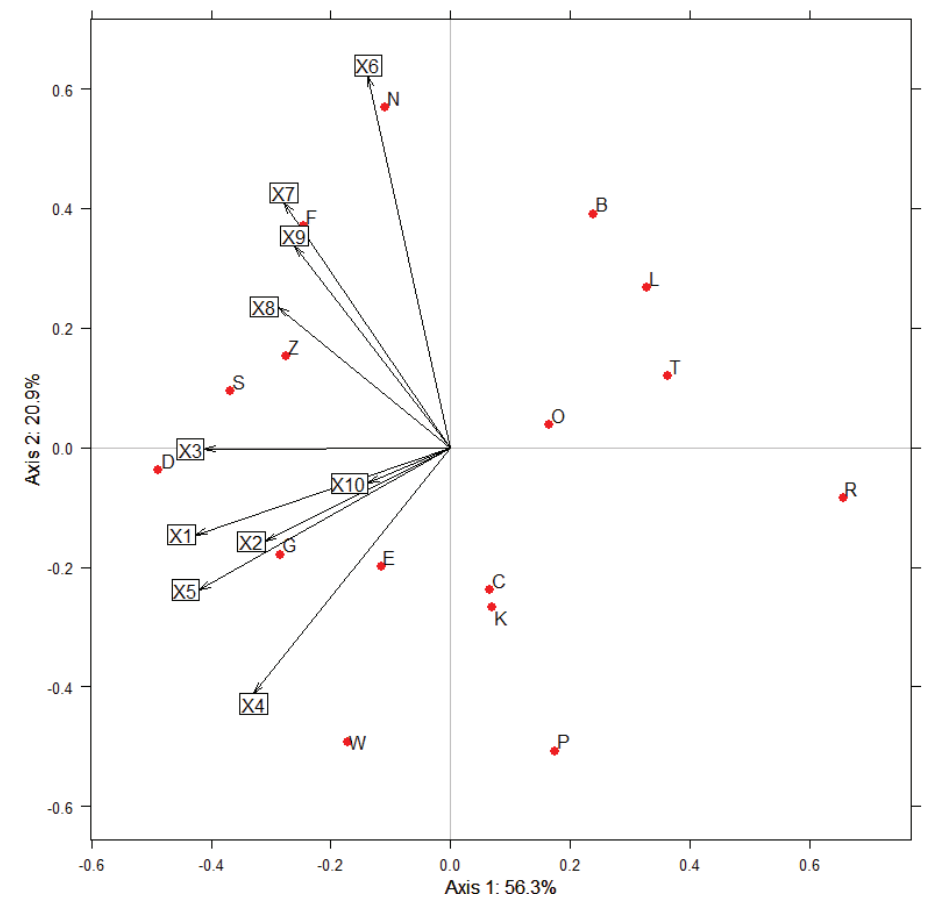

Legend: D - Dolnośląskie Voivodeship; C - Kujawsko-Pomorskie Voivodeship; L - Lubelskie Voivodeship; F - Lubuskie Voivodeship; E - Łódzkie Voivodeship; K - Małopolskie Voivodeship; W - Mazowieckie Voivodeship; O - Opolskie Voivodeship; R - Podkarpackie Voivodeship; B - Podlaskie Voivodeship; G - Pomorskie Voivodeship; S - Śląskie Voivodeship; T - Świętokrzyskie Voivodeship; N - Warmińsko-Mazurskie Voivodeship; P - Wielkopolskie Voivodeship; Z - Zachodniopomorskie Voivodeship.

Figure 4. The Compromise biplot

Source: own elaboration. 
An analysis of the Compromise biplot facilitates the assessment of the structure common to all of the annual tables. The first axis corresponds to the property crime gradient represented mainly by property damage $\left(\mathrm{X}_{1}\right)$, burglary $\left(\mathrm{X}_{3}\right)$ and property theft $\left(\mathrm{X}_{5}\right)$ with high levels of property crime towards the left and absence of property crime on the right. The second axis is strongly positively correlated with participation in violence or assault $\left(\mathrm{X}_{6}\right)$ and damage to health $\left(\mathrm{X}_{7}\right)$ so it corresponds to the crimes against life and health gradient (with a high crime rate towards the top of the biplot).

The points representing the voivodeships can be projected perpendicularly onto the vectors visualizing different types of crimes to obtain the approximate ordering of the voivodeships in order of increasing intensity of particular crimes. It can be observed straight away that the structure of the crime varies a lot in different voivodeships.

The hierarchical cluster analysis ( Ward's method) carried out on the two first axes scores of the voivodeships revealed that there are three clusters of voivodeships similar in terms of the crime rate: (1) Podkarpackie (R), Lubelskie (L), Podlaskie (B), Opolskie (O), Świętokrzyskie (T); (2) Wielkopolskie (P), Kujawsko-Pomorskie (C), Małopolskie (K), Pomorskie (G), Łódzkie (E), Mazowieckie (W) and (3) Lubuskie (F), Warmińsko-Mazurskie (N), Zachodniopomorskie (Z), Śląskie (S), Dolnośląskie (D) (see Figure 5).

The first cluster is characterized by a low level of crime against property, the second one - by a fairly high level of crime against property and a low level of crime against life and health, and the third one - by a high level of crime against life and health (in particular damage to health $-\mathrm{X}_{7}$, homicide $-\mathrm{X}_{8}$, rape $-\mathrm{X}_{9}$ ) and, in addition, in the Dolnośląskie, Śląskie and Zachodniopomorskie voivodeships - by a high level of crime against property.

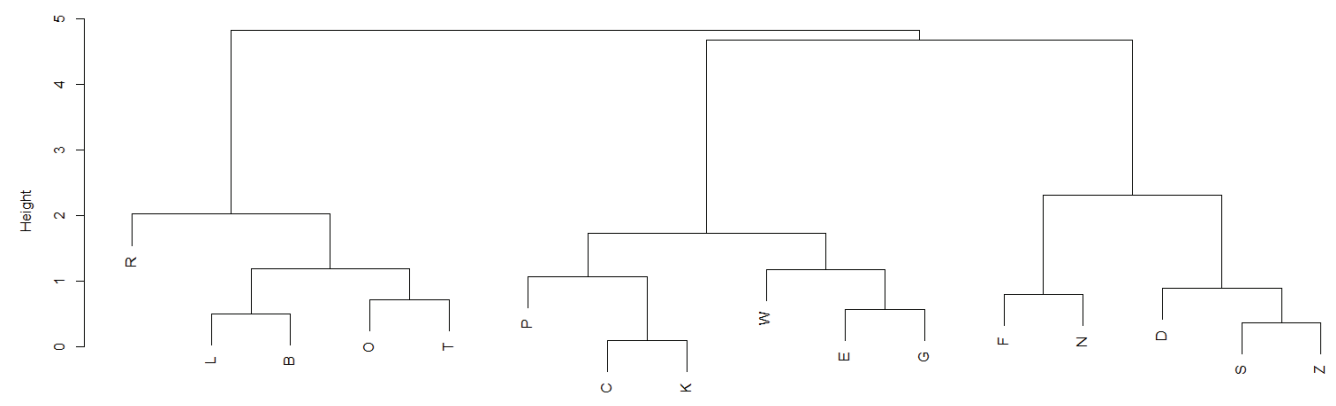

Legend as in Figure 4.

Figure 5. Clusters of voivodeships obtained by Ward's method

Source: own elaboration. 


\subsection{Intrastructure analysis and trajectories}

The Intrastructure step aims to assess the reproducibility of the Compromise across the series of $K$ tables. It is done by projecting the rows and columns of each of the 18 initial tables onto the Compromise space.

The results of the Intrastructure analysis are presented in Figures 6 to 11. The first column of the graphs represents the projection of the principal axes of the PCA of each table onto the Compromise space; the second one - the factor map (scatterplot) of voivodeships; the third one - the factor map of all types of the analyzed offences and the fourth one - the projection of the principal components of the PCA of each table onto the Compromise space.

The analysis of the Intrastructure graphs given in Figures 6 to 11 leads to the conclusion that the projection of axes resulting from the 18 separated PCAs overlaps well with those of the Compromise step. This is in accordance with the results of the Interstructure analysis, where a strong similarity between the initial annual tables was observed.
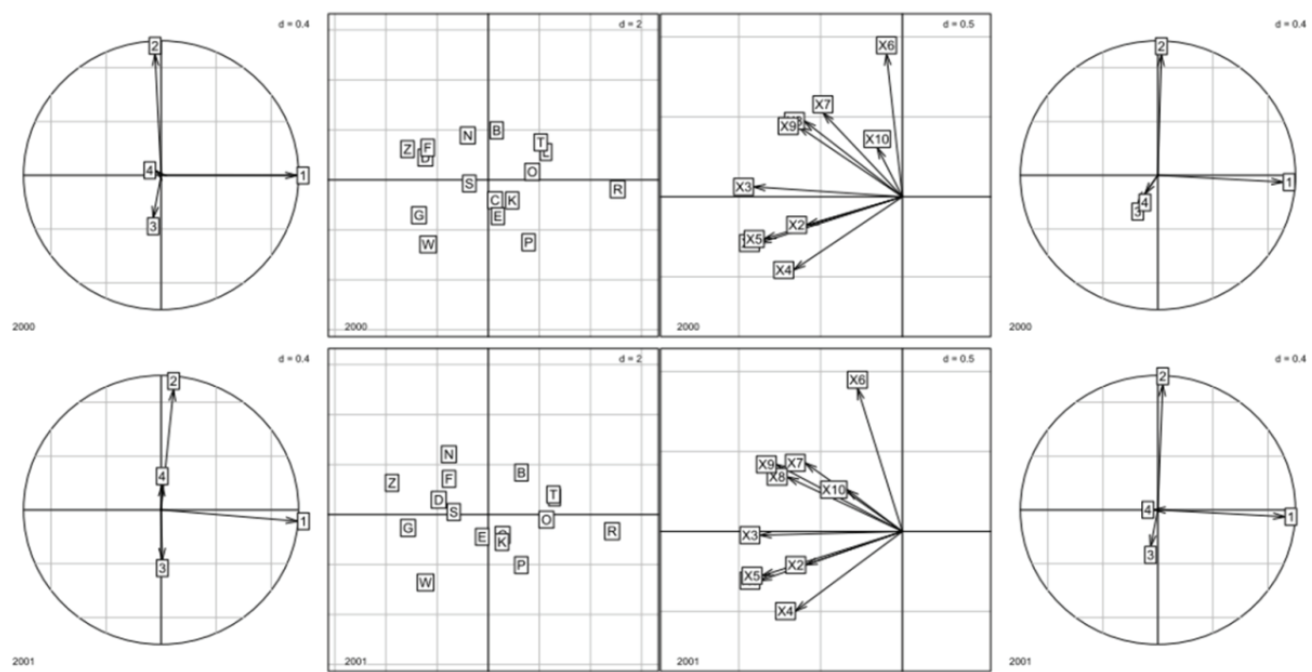

2001
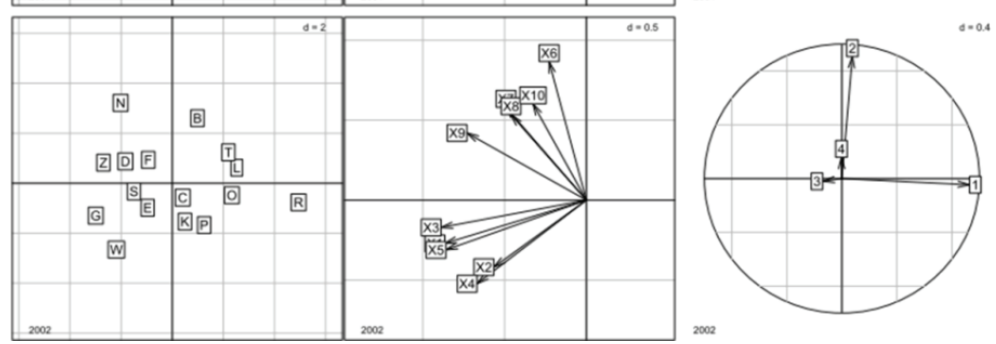

Figure 6. Analysis of the reproducibility of the Compromise structure for the years 2000-2002 Source: own elaboration. 


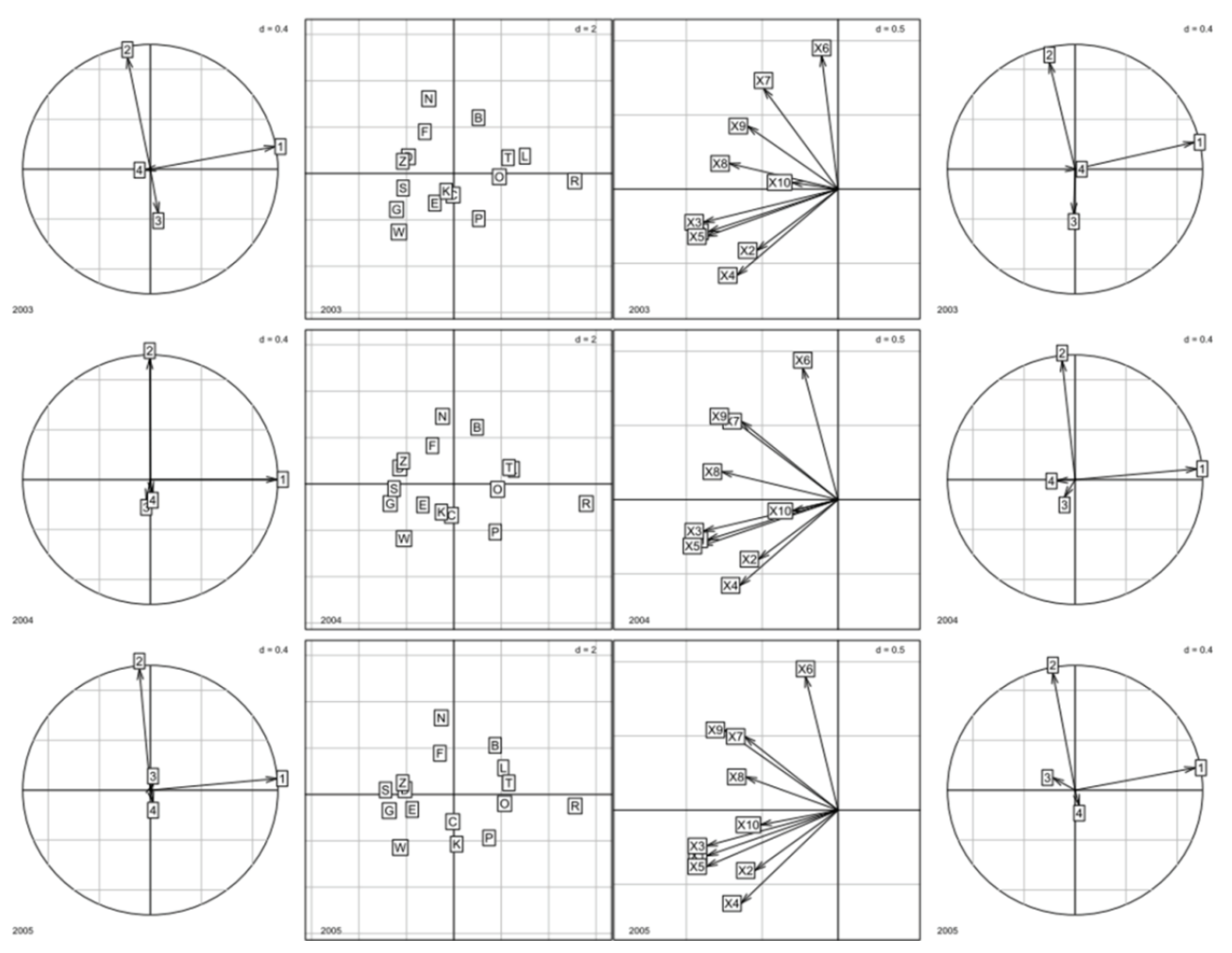

Figure 7. Analysis of the reproducibility of the Compromise structure for the years 2003-2005 Source: own elaboration. 


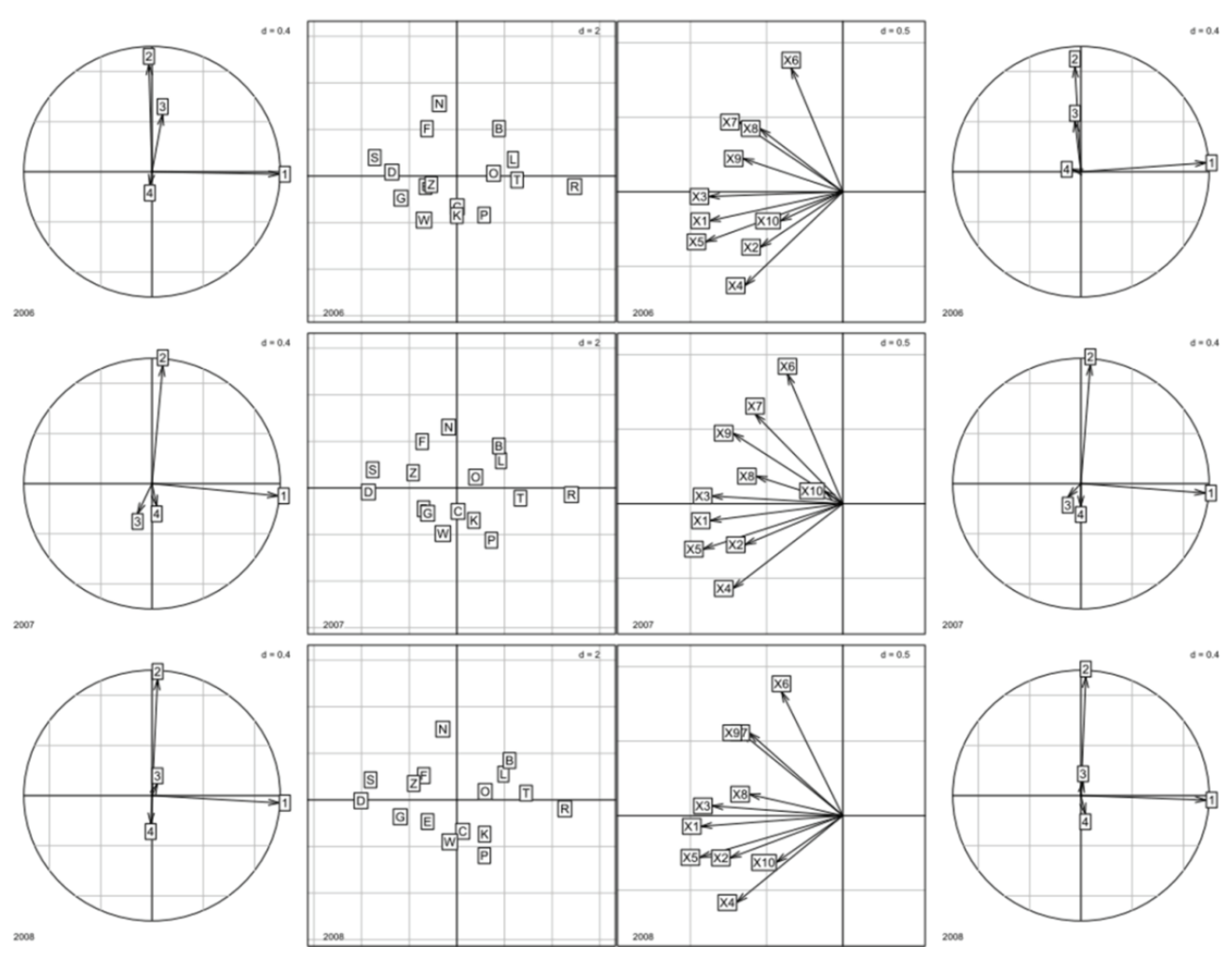

Figure 8. Analysis of the reproducibility of the Compromise structure for the years 2006-2008 Source: own elaboration. 


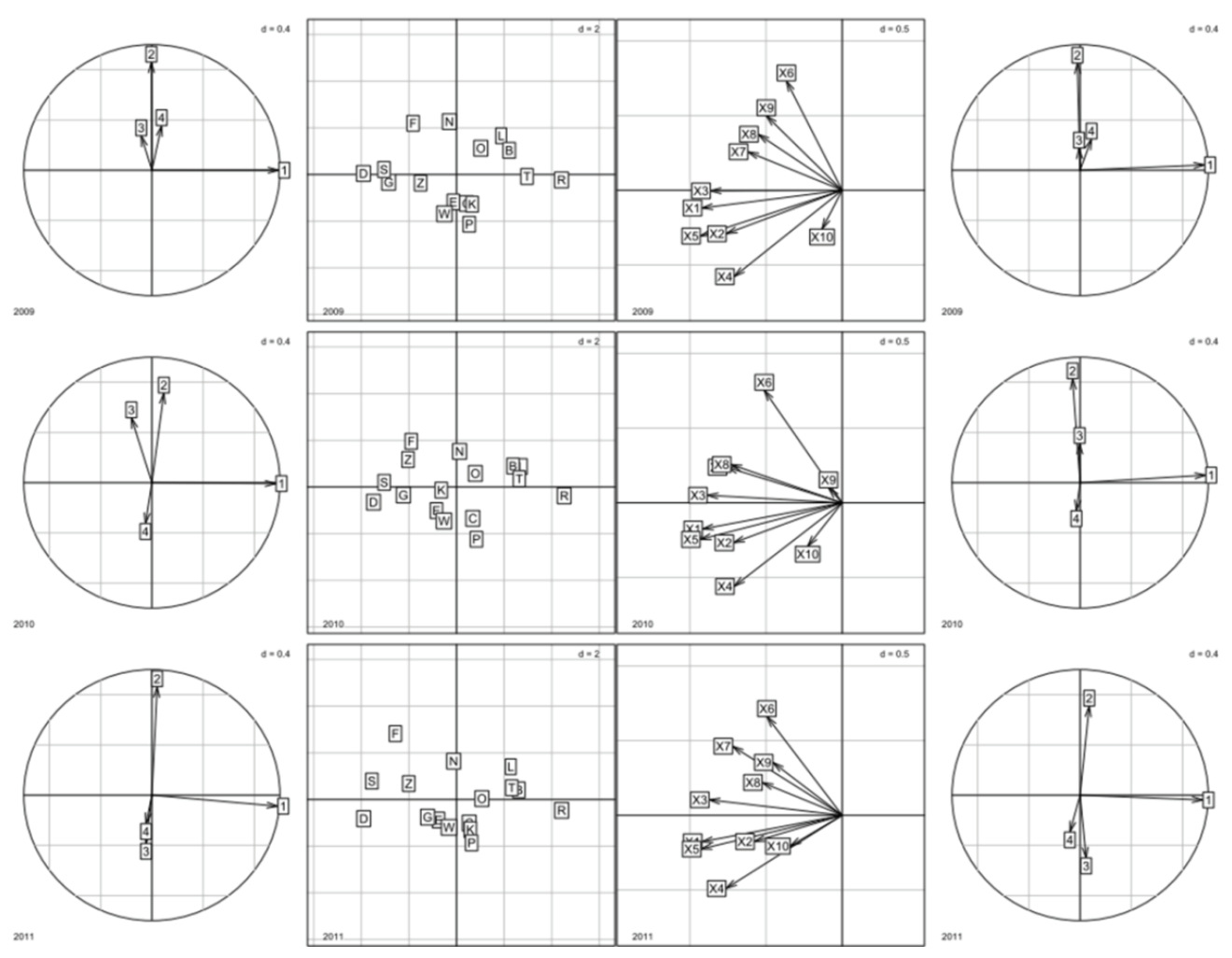

Figure 9. Analysis of the reproducibility of the Compromise structure for the years 2009-2011 Source: own elaboration. 


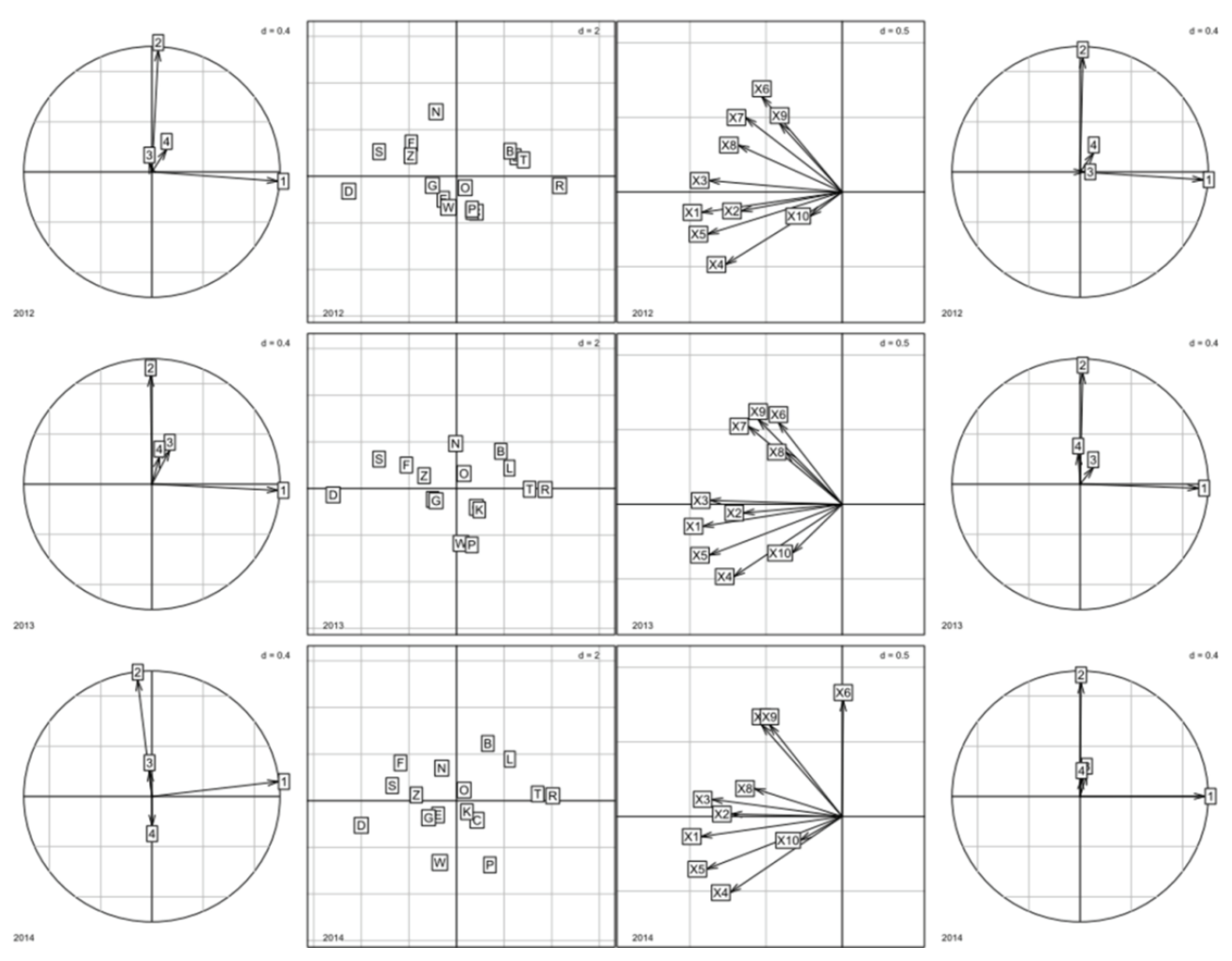

Figure 10. Analysis of the reproducibility of the Compromise structure for the years 2012-2014 Source: own elaboration. 


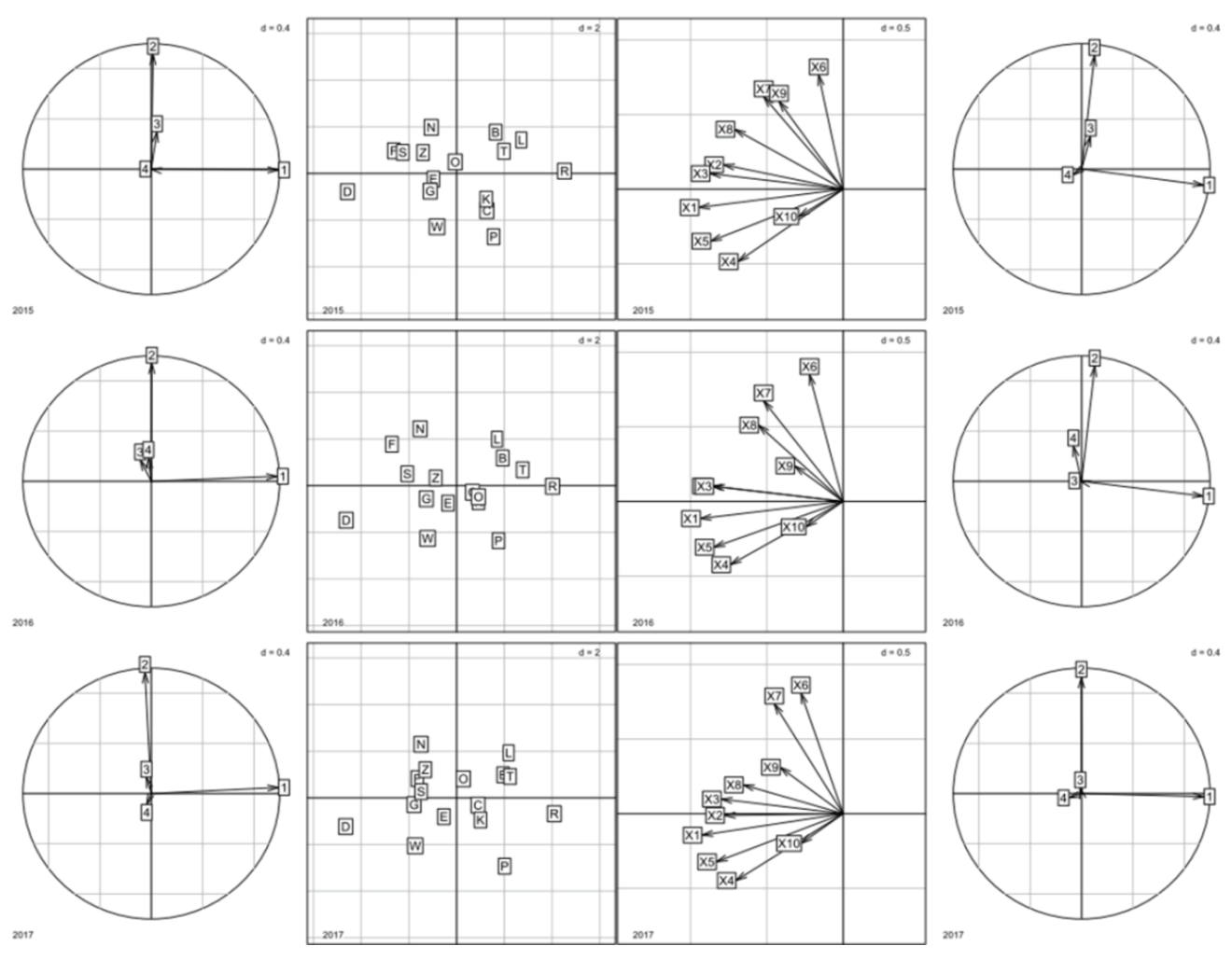

Figure 11. Analysis of the reproducibility of the Compromise structure for the years 2015-2017 Source: own elaboration. 
To assess the direction of the position changes of each voivodeship in the subsequent years (from year to year), trajectories factor maps can be applied (Figures 12-27).

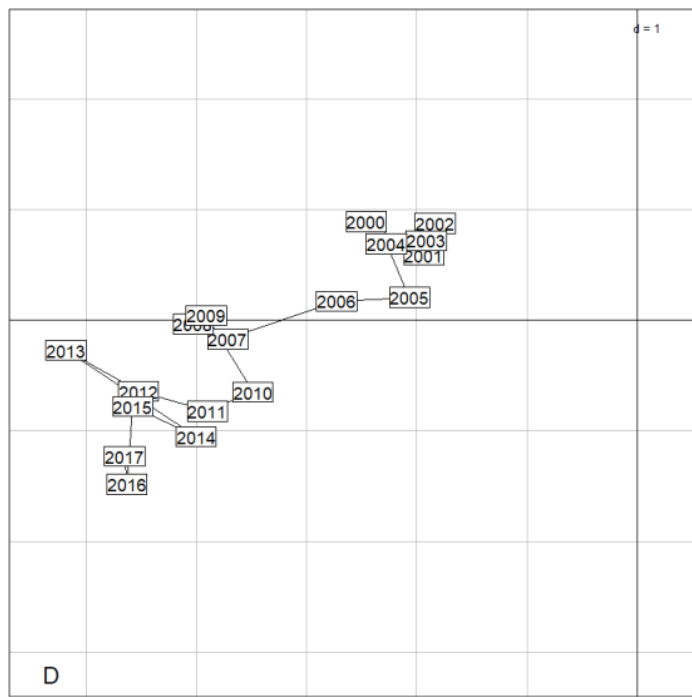

Figure 12. Trajectory for the Dolnośląskie Voivodeship

Source: own elaboration.

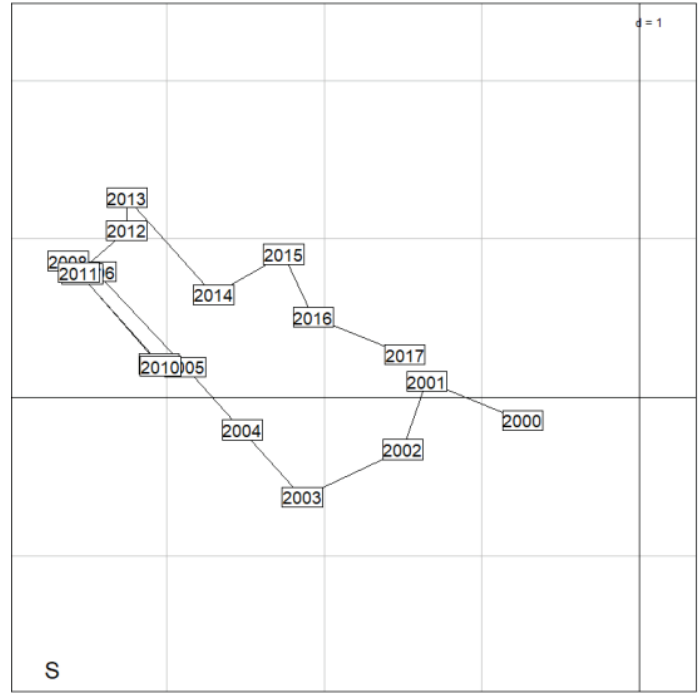

Figure 13. Trajectory for the Śląskie Voivodeship

Source: own elaboration. 


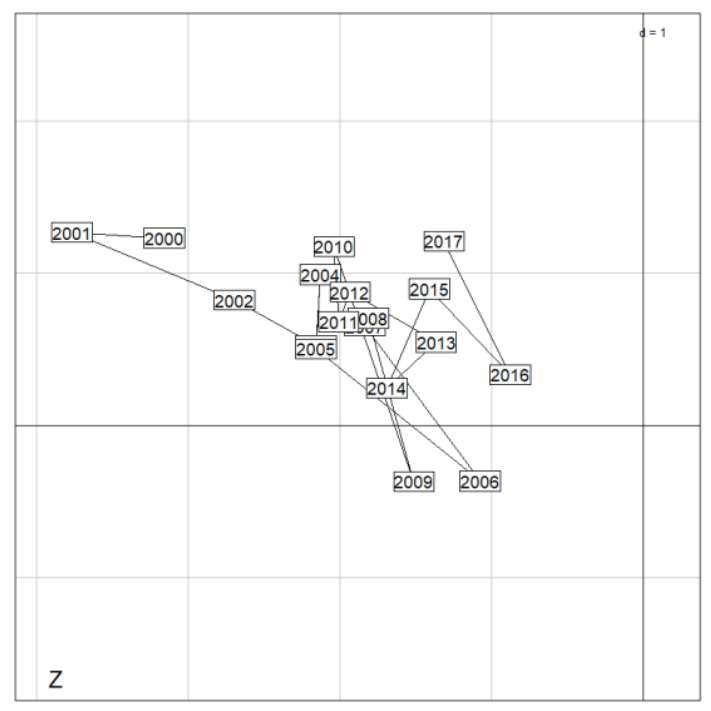

Figure 14. Trajectory for the Zachodniopomorskie Voivodeship

Source: own elaboration.

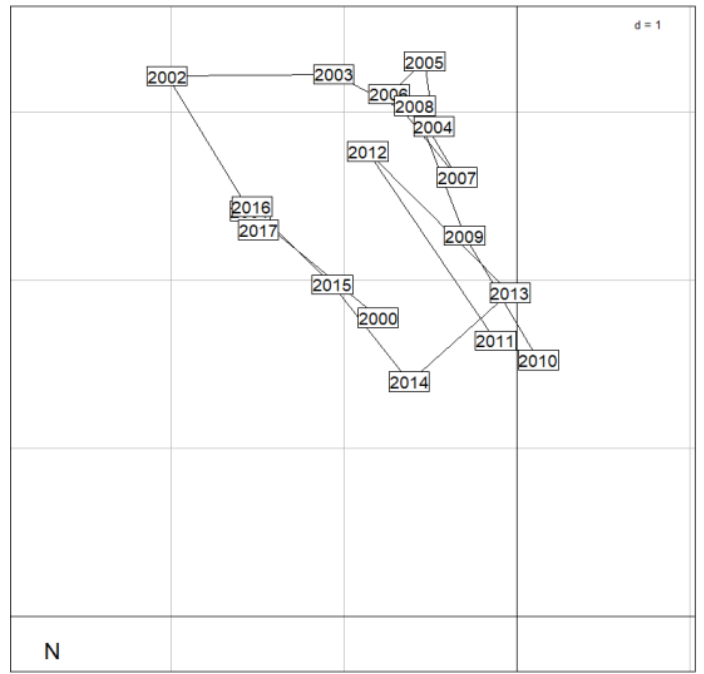

Figure 15. Trajectory for the Warmińsko-Mazurskie Voivodeship

Source: own elaboration. 


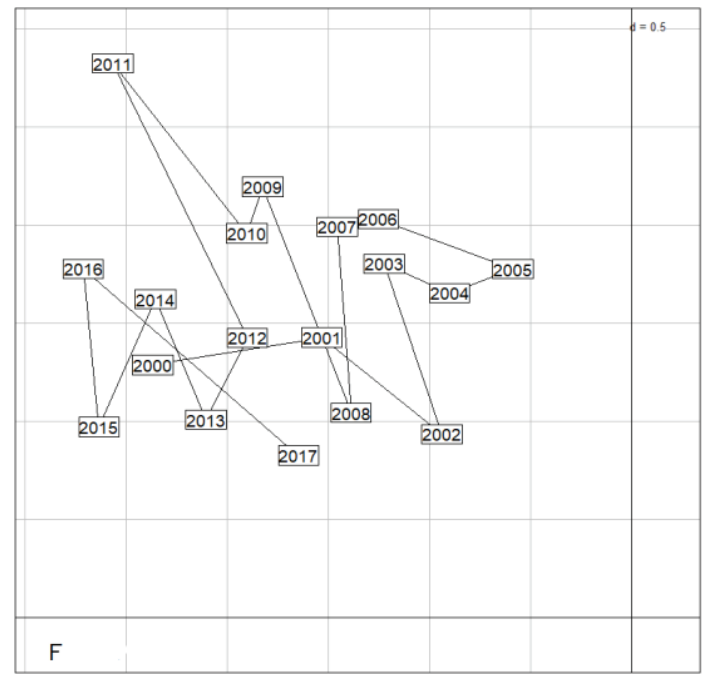

Figure 16. Trajectory for the Lubuskie Voivodeship

Source: own elaboration.

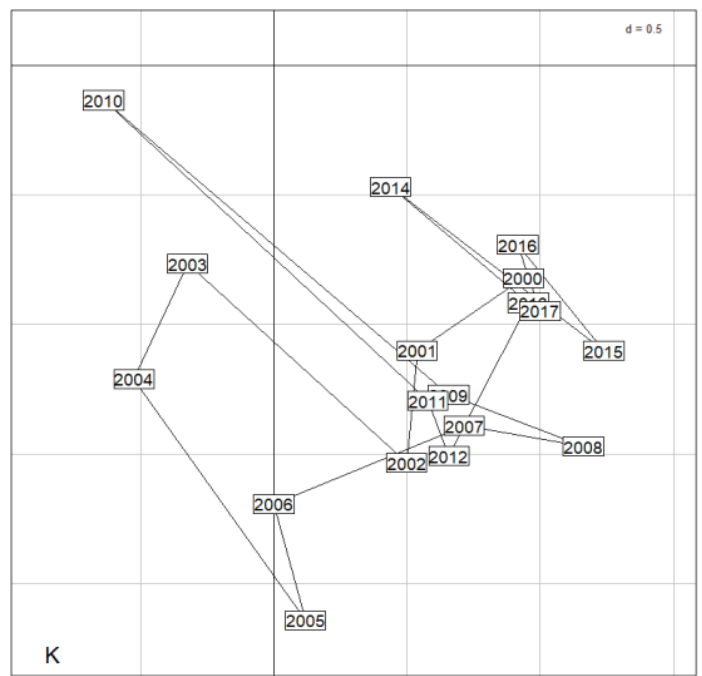

Figure 17. Trajectory for the Małopolskie Voivodeship

Source: own elaboration. 


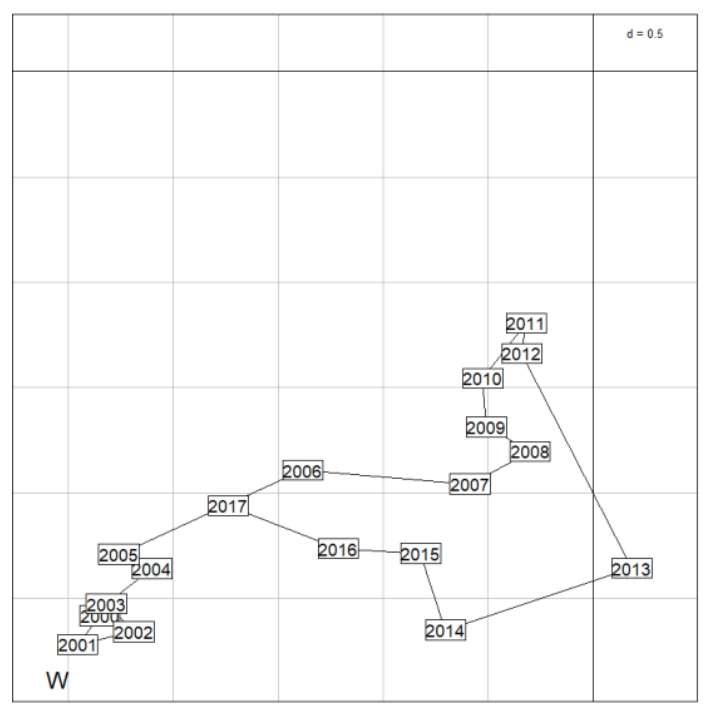

Figure 18. Trajectory for the Mazowieckie Voivodeship

Source: own elaboration.



Figure 19. Trajectory for the Łódzkie Voivodeship

Source: own elaboration. 


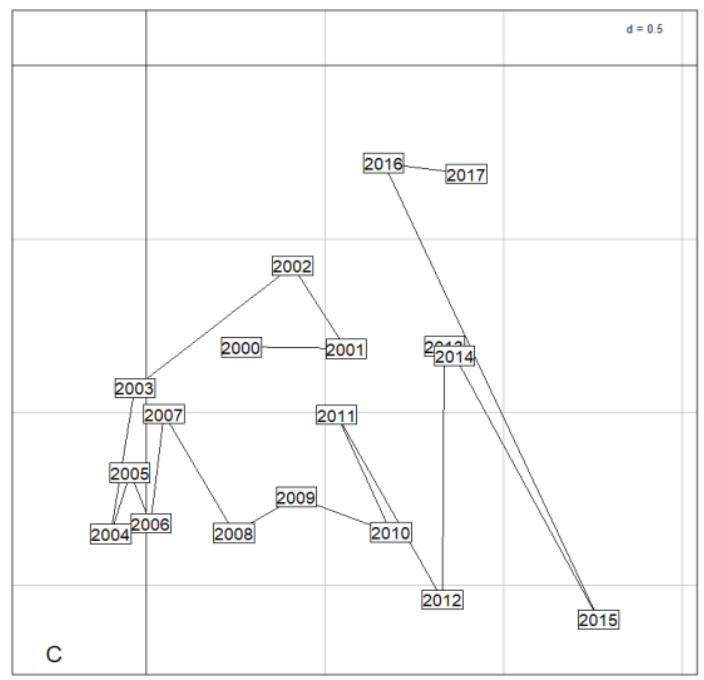

Figure 20. Trajectory for the Kujawsko-Pomorskie Voivodeship Source: own elaboration.

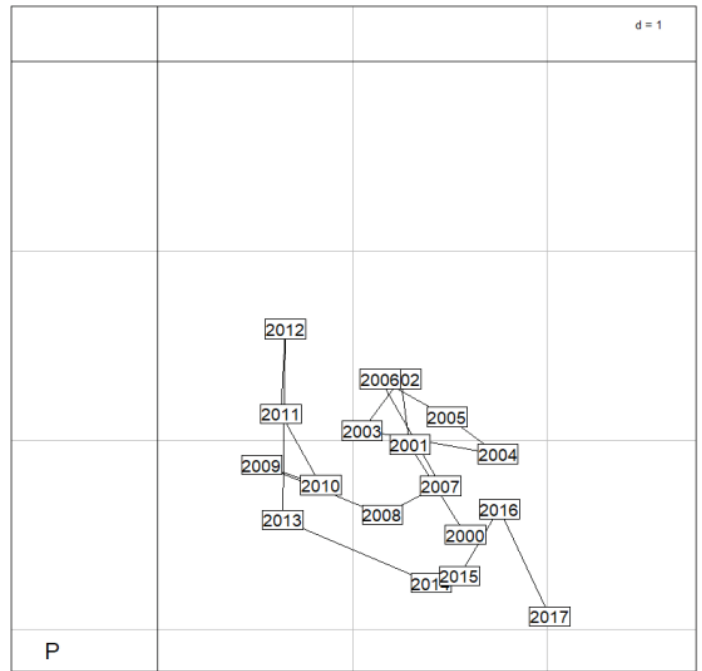

Figure 21. Trajectory for the Wielkopolskie Voivodeship

Source: own elaboration. 




Figure 22. Trajectory for the Pomorskie Voivodeship

Source: own elaboration.

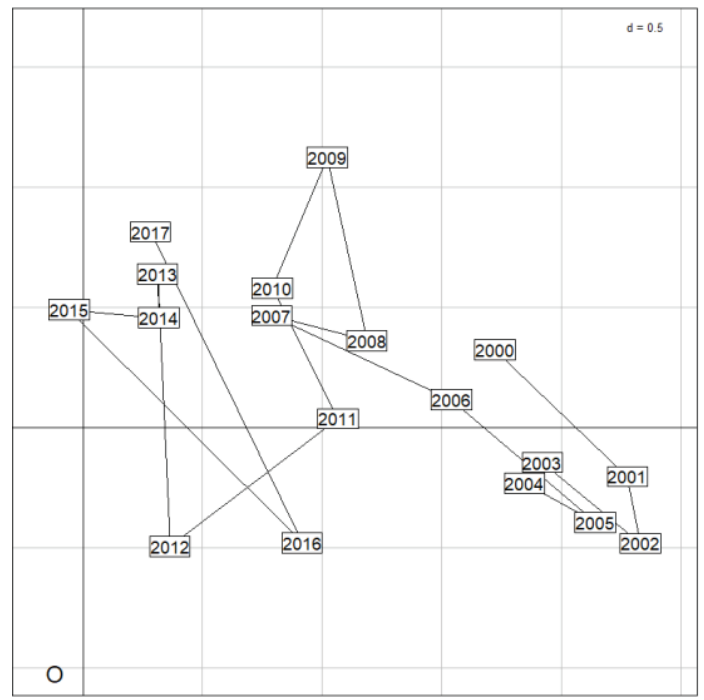

Figure 23. Trajectory for the Opolskie Voivodeship

Source: own elaboration. 


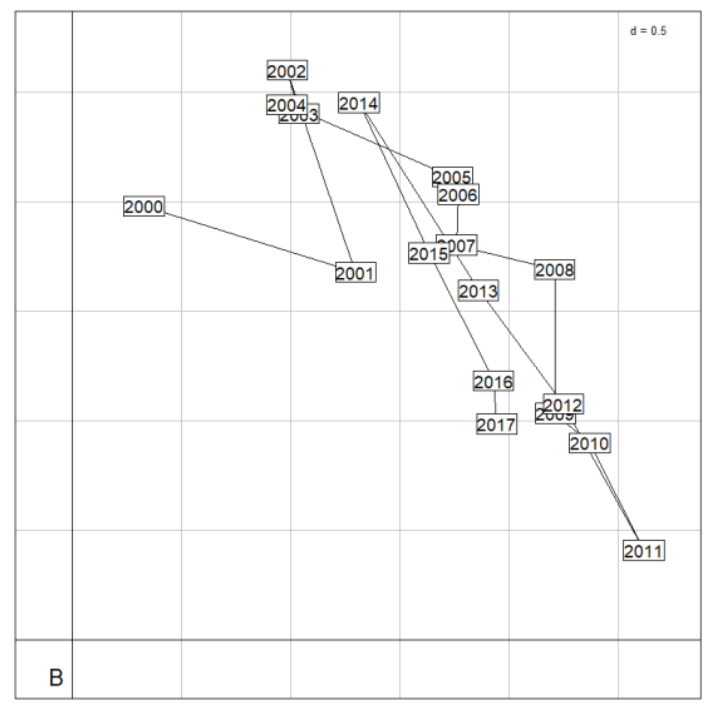

Figure 24. Trajectory for the Podlaskie Voivodeship

Source: own elaboration.

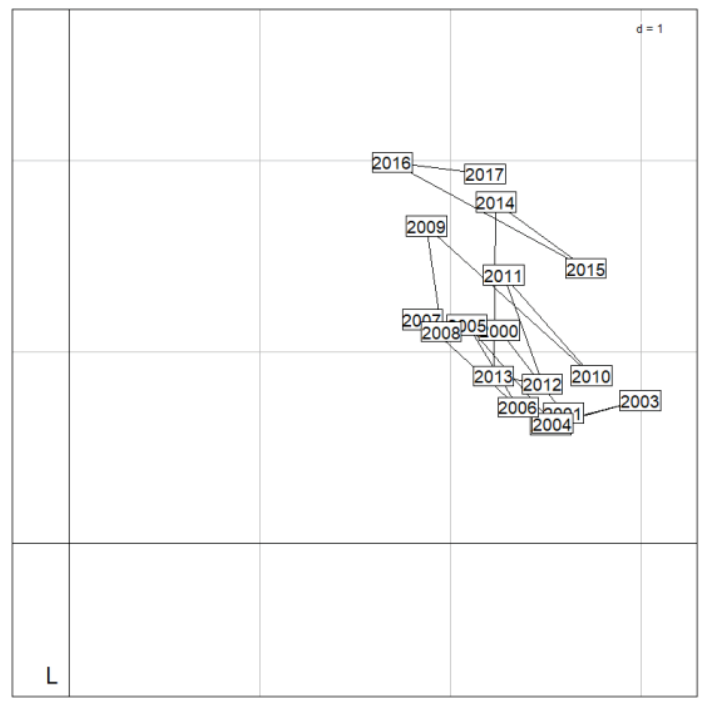

Figure 25. Trajectory for the Lubelskie Voivodeship

Source: own elaboration. 


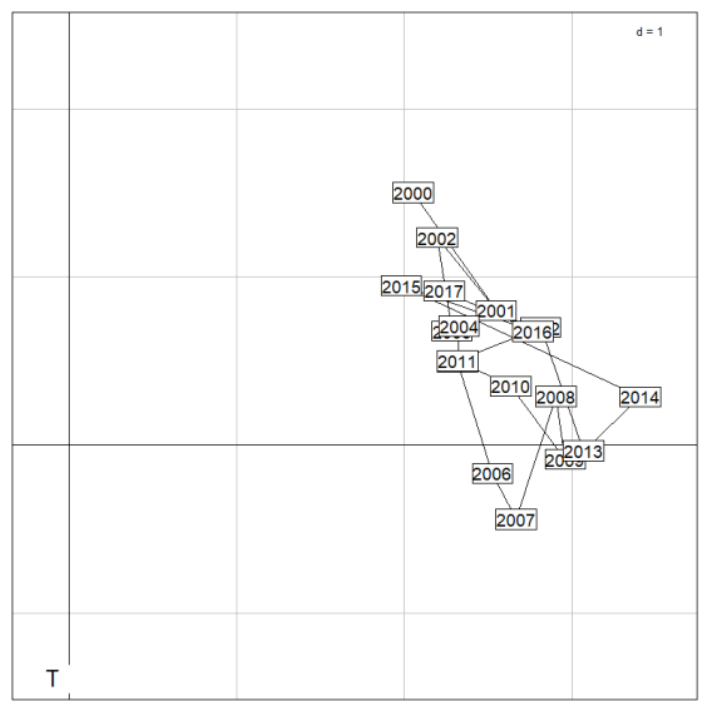

Figure 26. Trajectory for the Świętokrzyskie Voivodeship

Source: own elaboration.

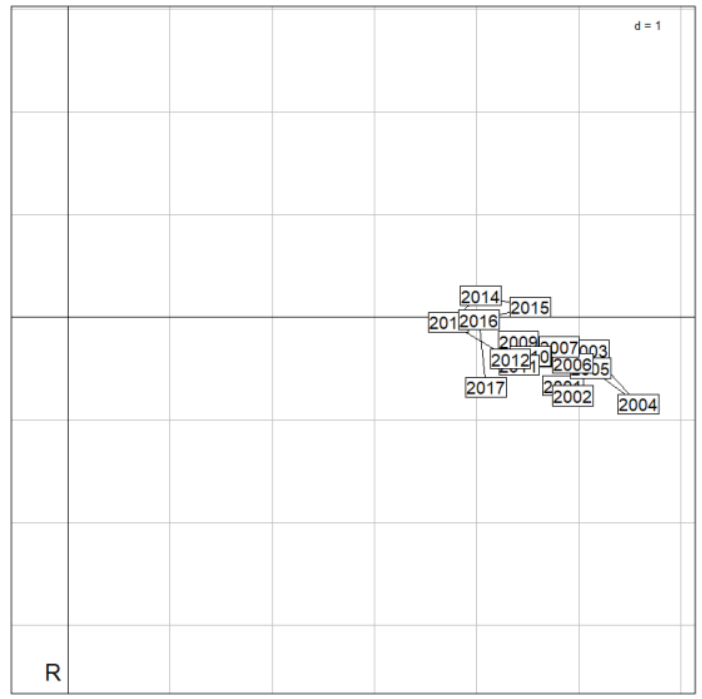

Figure 27. Trajectory for the Podkarpackie Voivodeship

Source: own elaboration.

An analysis of the results presented in Figures 12 to 27 reveals that the Podkarpackie Voivodeship (R) was characterized by the most stable structure of crime in the analyzed 
years. Similarly, the Wielkopolskie (P) and Lubelskie (L) Voivodeships were found to be characterized by a fairly stable structure of crime during the considered period.

Noticeable changes in the crime structure over time can be observed among others in the Opolskie (O), Dolnośląskie (D) and Mazowieckie (W) Voivodeships and also in the Podlaskie Voivodeship (B) and Małopolskie Voivodeship (K). As discussed above, the first axis of the Compromise corresponds to the property crime gradient, so the trajectories for the Opolskie and Dolnośląskie voivodeships arranged along the first axis from right to left indicate an increase in the crime against property rate, in both of the voivodeships in the subsequent years. Similarly, for the Mazowieckie Voivodeship, changes occur along the first axis of the Compromise, first a decrease in the level of crime against property is observed (until 2007/2008) and then an increase from 2013. In contrast, the trajectory for the Podlaskie Voivodeship is elongated in relation to the second axis of the Compromise, representing the crime against life and health gradient (a decrease in the crime level until 2011 and then an increase). In the Małopolskie

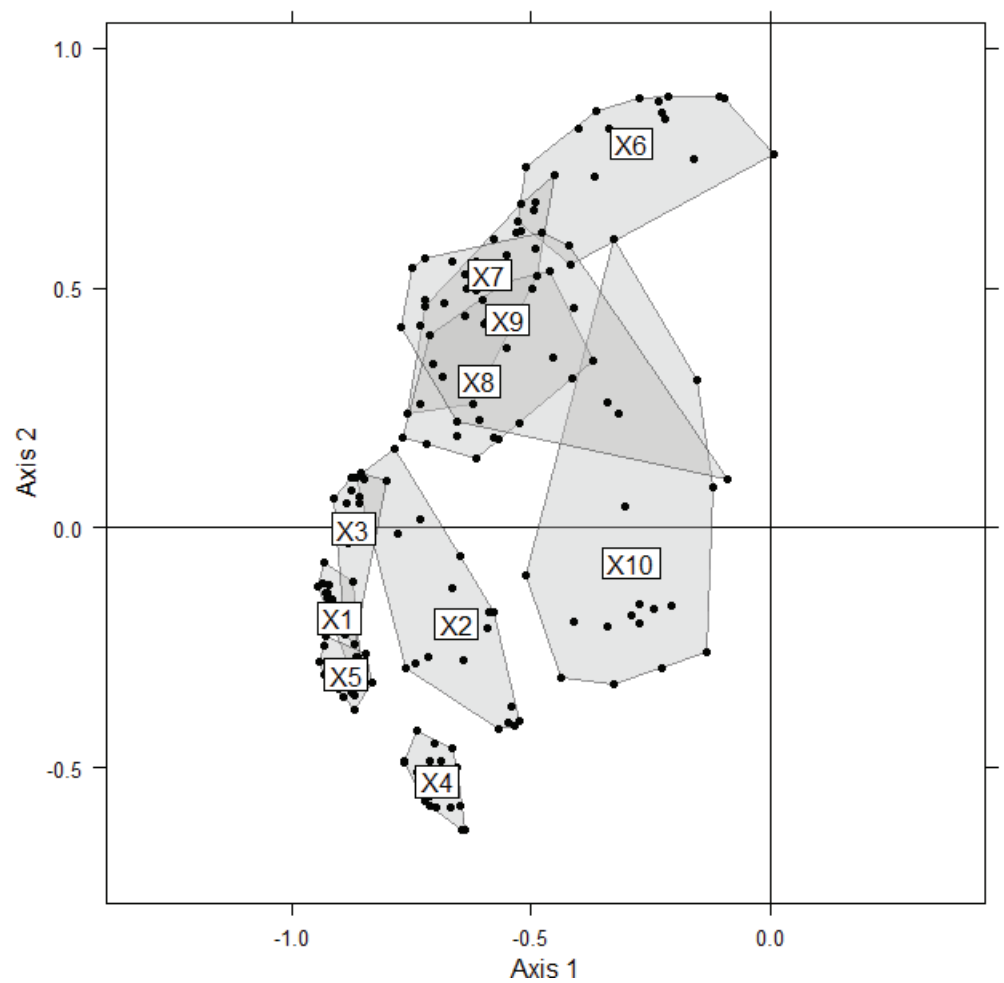

Figure 28. Temporal variability of the analyzed 10 types of crimes 
Voivodeship in the years 2003-2004 and also in 2010 a visible increase in crime against life and health was observed.

It is also possible to assess the temporal variability of the 10 analyzed types of criminal offences. The results are presented in Figure 28 (projections of variables loadings obtained for the separate PCAs on the first and second axes of the Compromise in the form of the centroid with the convex hull of the variable corresponding each crime). The $\mathrm{X}_{10}$ (drugs) variability, as well as, $\mathrm{X}_{2}$ (robbery) and $\mathrm{X}_{9}$ (rape), is clearly distinguished from the others.

\section{Conclusions}

The use of the Partial Triadic Analysis method for the analysis of the crime data in Poland allowed successfully meeting the aims of the study.

The PTA Interstructure step revealed the similarities between the tables corresponding to the analyzed 18 years. The tables representing the years 2000 and 2002 as well as 2016 and 2017 were the most different from the others as their contribution to the common part (Compromise) was the smallest. It also should be noted that the tables for the years 2007 and 2008 contributed the most to the Compromise. However, the weights for all 18 years were quite similar, so it can be concluded that all the tables were structured in a similar way (i.e. the structure of crime by voivodeship was fairly stable during the analyzed period).

The PTA Compromise step allowed highlighting the stable structure in the analyzed sequence of tables. The quality of the Compromise over $79 \%$ can be considered as satisfactory. The analysis of the Compromise biplot made it possible to identify groups of voivodeships similar in terms of crime structure and to determine the dominant type of crime (crime against property or crime against life and health). The obtained results are consistent with other studies (e.g. Kądziołka, 2015c, 2016a) and complement the research by Misztal (2019).

The PTA Intrastructure step facilitated the assessment of the variability of the analyzed sequence of tables in comparison with the common part defined by the Compromise. Only slight differences were observed between the results from the 18 separate PCAs and the results of the Compromise step. This confirms the information given by the quality index of the Compromise's structure $\left(\cos ^{2}\right)$ evaluated in the Interstructure step. Trajectory factor maps made it possible to assess how stable the position of particular voivodeships was over time. Even if the positions of voivodeships are not exactly identical year by year, it can be seen that only a few voivodeships (e.g. Opolskie, Dolnośląskie, Mazowieckie) are characterized by greater variability in the structure of crime. However, it should be emphasized that for the majority of voivodeships 
the trajectories remain in the same area of the Compromise plot. The highest variability in the analyzed years was observed for variable $\mathrm{X}_{10}$ - crimes under The Act on Counteracting Drug Addiction. In that case, high variability may be related to numerous amendments to the Act on Counteracting Drug Addiction with the expanding list of drugs.

The possibility of the PTA method to highlight the stable structure in a sequence of tables is considered to be one of the advantages of this method. The determination of a stable structure in the analyzed data and the identification of voivodeships similar in terms of the level of crime may facilitate the process of developing adequate crime-fighting strategies.

Although the level of crime in Poland is noticeably decreasing, monitoring and analysing crime data should be recommended to the relevant institutions. Thus, the scale and nature of selected types of crime, especially the most serious ones, can be assessed on an ongoing basis. The presentation of positive trends supported by the results of the statistical analyses, increases, inter alia, the feeling of safety in Polish society. Scientific studies on crime statistics should also support preventive measures taken by the police to combat crime.

The Partial Triadic Analysis is an exploratory data analysis method handling three-way data structures with good visualization properties. The possibility of a graphical presentation of the results using scatterplots and biplots, and the potentiality to draw conclusions directly from the analysis of the factorial maps, are often mentioned as other advantages of this method. The Compromise plots and the trajectories factor maps allow assessing the similarities and dissimilarities between objects and help to identify the variables responsible for the dissimilarities. On the other hand, it should be stressed that PTA, as an exploratory data analysis tool, does not allow building formal, mathematical models of the investigated phenomena. Therefore, more formal methods of a spatial-temporal data analysis should also be considered to be applied. This will be the subject of further research.

\section{References}

Abdi, H., Valentin, D. (2007). The STATIS method. In: N. Salkind (ed.), Encyclopedia of Measurement and Statistics (pp. 955-963). Thousand Oaks (CA): SAGE Publications.

Abdi, H., Williams, L.J., Valentin, D., Bennani-Dosse, M. (2012). STATIS and DISTATIS: optimum multitable principal component analysis and three way metric multidimensional scaling. WIREs Comput Stat, 4, 124-167. DOI: 10.1002/wics.19. 
Bąk, I. (2015). Struktura i typologia przestrzenna przestępczości w Polsce. Ekonometria, 4 (50), 43-61.

Bąk, I., Cheba, K. (2018). Przestępczość w krajach członkowskich Unii Europejskiej - analiza statystyczna. Studia i Prace WNEiZ US, 54/3, 57-69. DOI: 10.18276/sip.2018.54/3-04.

Bąk, I., Szczecińska, B. (2015). Statystyczna analiza przestępczości w województwach Polski. Folia Pomeranae Universitatis Technologiae Stetinensis, Oeconomica, 323 (81)4, 5-14.

Bieniek, P., Cichocki, S., Szczepaniec M. (2012). Czynniki ekonomiczne a poziom przestępczości - badanie ekonometryczne. Zeszyty Prawnicze, 12 (1), 147-172.

Escoufier, Y. (1973). Le traitement des variables vectorielles. Biometrics, 29 (4), 751-760. DOI: $10.2307 / 2529140$.

Florczak, W. (2013). Co wywotuje przestępczość i jak ją można ograniczać? Wielowymiarowa analiza makroekonomiczna. Łódź: Wydawnictwo Uniwersytetu Łódzkiego.

Kądziołka, K. (2014). Wpływ wybranych czynników o charakterze społeczno-ekonomicznym na przestępczość przeciwko mieniu w Polsce. Studia Ekonomiczne, 181, 11-23.

Kądziołka, K. (2015a). Analiza czynników wpływających na przestrzenne zróżnicowanie przestępczości w Polsce na poziomie podregionów. Współczesna Gospodarka, 6 (3), 43-52.

Kądziołka, K. (2015b). Bezrobocie, ubóstwo i przestępczość w Polsce. Analiza zależności na poziomie województw. Studia Ekonomiczne. Zeszyty Naukowe Uniwersytetu Ekonomicznego $w$ Katowicach, 242, 71-84.

Kądziołka, K. (2015c). Przestrzenne zróżnicowanie, struktura i dynamika przestępczości w Polsce. Przestrzeń, Ekonomia, Społeczeństwo, 8/II, 223-235.

Kądziołka, K. (2016a). Analysis of the crime rate in Poland in spatial and temporal terms. Central and Eastern European Journal of Management and Economics, 4 (1), 81-96.

Kądziołka, K. (2016b). Przestrzenne zróżnicowanie zagrożenia przestępczością w Polsce. De Securitate et Defensione. O Bezpieczeństwie i Obronności, 2 (2), 31-43.

Kądziołka, K. (2016c). Determinanty przestępczości w Polsce. Analiza zależności z wykorzystaniem drzew regresyjnych. Ekonomia. Rynek, gospodarka, społeczeństwo, 45, 53-81. DOI: $10.17451 / \mathrm{eko} / 45 / 2016 / 186$.

Leżoń, A. (2015). Przestępczość w krajach Unii Europejskiej w roku 2012 - rezultaty wielowymiarowej analizy statystycznej. In: A. Prędki (ed.), Wybrane zastosowania narzędzi analitycznych w naukach ekonomicznych (pp. 25-33). Kraków: Mfiles.pl.

Lusawa, R. (2016). Zróżnicowanie liczby przestępstw stwierdzonych w wybranych powiatach województwa mazowieckiego. Roczniki Naukowe Ekonomii Rolnictwa i Rozwoju Obszarów Wiejskich, 103 (2), 91-105.

Misztal, M. (2017). On the use of redundancy analysis to study the property crime in Poland. Acta Universitatis Lodziensis. Folia Oeconomica, 6 (332), 99-109. 
Misztal, M. (2018). O zastosowaniu analizy redundancji do badania poziomu przestępczości przeciwko mieniu w Polsce w latach 2002-2015. Taksonomia, 31. Klasyfikacja i analiza danych - teoria i zastosowania. Prace Naukowe Uniwersytetu Ekonomicznego we Wroctawiu, 508, 157-169.

Misztal, M. (2019). On the potential for using selected PCA-based methods to analyze the crime rate in Poland. Econometrics. Ekonometria. Advances in Applied Data Analysis, 23 (2), 15-32. DOI: 10.15611/eada.2019.2.02.

Mordwa, S. (2013). Zastosowanie GIS w badaniach przestępczości. Acta Universitatis Lodziensis. Folia Geographica Socio-Economica, 14, 78-92.

Robert, P., Escoufier, Y. (1976). A Unifying Tool for Linear Multivariate Statistical Methods: The RV-Coefficient. Journal of the Royal Statistical Society. Series C (Applied Statistics), 25 (3), 257-265. DOI: 10.2307/2347233.

Stanimirova, I., Walczak, B., Massart, D.L., Simeonov, V., Saby, C.A., Di Crescenzo, E. (2004). STATIS, a three-way method for data analysis. Application to environmental data. Chemometrics and Intelligent Laboratory Systems, 73, 219-233.

Sztaudynger, J.J., Sztaudynger, M. (2003). Ekonometryczne modele przestępczości. Ruch Prawniczy, Ekonomiczny i Socjologiczny, LXV (3), 127-143.

Thioulouse, J. (2011). Simultaneous analysis of a sequence of paired ecological tables: a comparison of several methods. The Annals of Applied Statistics, 5 (4), 2300-2325. DOI: 10.1214/10-AOAS372.

Thioulouse, J., Dray, S., Dufour, A.-B., Siberchicot, A., Jombart, T., Pavoine S. (2018). Multivariate Analysis of Ecological Data with ade4. New York: Springer.

Wierzbicka, A., Żółtaszek, A. (2015). Analiza bezpieczeństwa publicznego w krajach europejskich. Wiadomości Statystyczne, 8, 66-80. 